\title{
The Applications of Undyed and Dyed Wool Fabrics Treated with $\mathrm{CuO}$ Nanoparticles
}

\author{
Özlen ALTUN ${ }^{* 1}$, Nilgün BECENEN ${ }^{2}$
}

\begin{abstract}
In this study, application to undyed and dyed fabrics and testing of finished fabrics for hydrophobic wettability and antimicrobial activity of $\mathrm{CuO}$ nano materials was investigated. It was observed that applying $\mathrm{CuO}$ nanomaterials to dyed wool rendered the fabric hydrophobic from contact angle measurements. Also, the nano-CuO-impregnated undyed and dyed wool fabrics (100\% wool) showed excellent antibacterial activity against Staphylococcus aureus, Escherichia coli and Escherichia coli isolated from pasta.
\end{abstract}

Keywords - CuO Nanomaterials, Wool Fabric, Contact Angle, Antibacterial Activity.

\section{INTRODUCTION}

Inorganic nanomaterials, such as metal and metal oxide nanoparticles, have received attention in recent years because of their applications for antimicrobial activity [1,2], magnetic devices [3] and photocatalysis [4]. The intrinsic properties of a metal oxide nanoparticle are mainly determined by size, shape, crystallinity and composition [5]. It is reported in the literature that $\mathrm{ZnO}$ nanoparticles can be applied to cotton [6], wool [7. 8] and silk fabrics to impart UV protection and antimicrobial efficacy.

Copper oxide nanoparticles are a brownish-black powder. They can be reduced to metallic copper when exposed to hydrogen or carbon monoxide at high temperatures. They are graded as harmful to humans and dangerous for the environment with adverse effects on aquatic life. They can be used as catalysts, superconducting materials, thermoelectric materials, sensing materials in glass, ceramics and other materials.

The main aim of this study is to determine the application to fabrics of $\mathrm{CuO}$ nanomaterials and to test the finished fabric for hydrophobic wettability and antibacterial activity.

\section{II.EXPERIMENTAL}

\section{A. General procedure for application to wool fabric}

Two types of washed $100 \%$ wool fabric with a weight of $260 \mathrm{~g} / \mathrm{m}^{2}$ undyed and dyed with synthetic dye were used in the experiments. $\mathrm{CuO}$ nanomaterials were sprayed onto the wool fabrics using a spray-gun $[9,10]$.

\footnotetext{
${ }^{1}$ Trakya University, Department of Chemistry, 22030 Edirne/TURKEY

${ }^{2}$ Trakya University, Vocational College of Technical Sciences, Department of Chemistry, 22030 Edirne/TURKEY

*Corresponding author: Trakya University, Department of Chemistry, 22030Edirne/TURKEY
}

Nanomaterials were applied onto the face side of the wool fabrics at a concentration 1\%, material-to-liquor ratio 1:20, and with $3 \%$ acrylic binder. These fabrics were coated with $\mathrm{CuO}$ nanomaterials using a spray-gun. The hand spray-gun was filled with a dispersion of nanomaterials. The fabric substrate was fixed on a vertical board. The nanomaterial solution was evenly sprayed over the wool fabric by maintaining a constant distance between the fabric and spraygun nozzle. The excess solution was squeezed out using a padding mangle. After padding, the wool fabrics were dried at $130^{\circ} \mathrm{C}$ and were sun-fixed at $190^{\circ} \mathrm{C}$.

\section{B. Hydrophobic wettability procedure}

The contact angle $[11,12]$ is an important parameter for determining the hydrophobicity of surfaces. Contact angle, $\theta$, is a quantitative measure of wetting of a textile's surface by a liquid. It is defined geometrically as the angle formed by a liquid at the three-phase boundary where a liquid, gas and solid intersect. The well-known Young equation describes the balance at the three-phase contact of solid-liquid and gas,

$$
\gamma_{\mathrm{lv}} \cos \theta \mathrm{Y}=\gamma_{\mathrm{sv}}-\gamma_{\mathrm{sl}}
$$

where $\gamma_{\mathrm{lv}}, \gamma_{\mathrm{sv}}$, and $\gamma_{\mathrm{sl}}$ represent the liquid-vapour, solidvapour, and solid-liquid interfacial tensions, respectively, and $\theta \mathrm{Y}$ is the contact angle. Equation (1) is usually referred to as the Young's equation, and $\theta \mathrm{Y}$ is the Young's contact angle. If the water contact angle is $<90^{\circ}$, the textile surface is called a hydrophilic surface, and if it is $>90^{\circ}$, the textile surface is considered hydrophobic. If the contact angle even is greater than $150^{\circ}$ these are called superhydrophobic surfaces.

\section{Antibacterial activity procedure}

To investigate the in vitro antibacterial activity, wool fabric impregnation was completed separately with $\mathrm{CuO}$ nanomaterials. Antibacterial test AATCC-100 [13, 14] was carried out against Staphylococcus aureus (Gram-positive bacteria), Escherichia coli (Gram-negative bacteria) and Escherichia coli isolated from pasta (Gram-negative bacteria). The percentage reduction of bacteria on the $100 \%$ wool yarns is reported as $\mathrm{R}$,

$$
\mathrm{R}(\%)=100 \times(\mathrm{A}-\mathrm{B} / \mathrm{A})
$$

where $\mathrm{R}$ is \% reduction, $\mathrm{A}$ is the number of bacteria on the untreated wool fabric after 24 hours and B is the number of bacteria on the treated wool fabric after 24 hours. 


\section{ResUlt AND Discussion}

3.1. Analysis of the wool fabric finished with $\mathrm{CuO}$ nanomaterials using SEM

The surfaces of treated and untreated wool fabrics were observed with SEM. Figure $1 \mathrm{a}$ and $1 \mathrm{~b}$ show SEM images of the untreated undyed wool fabric and synthetically dyed wool fabric. Figure $2 \mathrm{a}$ and $1 \mathrm{~b}$ show SEM micrographs of the same wool fabric samples treated with $\mathrm{CuO}$ nanomaterials, respectively. The $\mathrm{CuO}$ nanoparticles are well dispersed on the wool fabric surfaces, although some aggregated nanomaterials are still visible. The particle size plays a primary role in determining their adhesion to the wool fabric. It is reasonable to expect that the largest particle agglomerates will be easily removed from the wool fabric surface, while the smaller particles will penetrate deeper and adhere strongly to the fabric matrix.

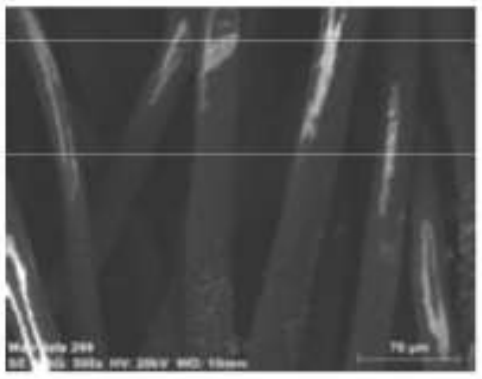

(a)

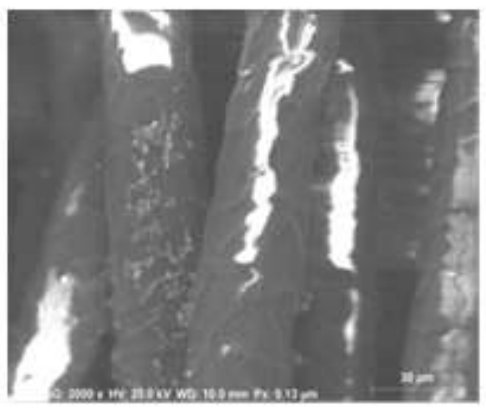

(b)

Fig. 1. SEM images of untreated (a) undyed wool fabric (b) synthetically dyed wool fabric

\subsection{Hydrophobic wettability results}

The contact angle values of $\mathrm{CuO}$ nanomaterial-untreated and -treated dyed wool fabrics were measured with a KSV/Attension Theta Tensiometer (Figure 4). As seen in Figure 4, water drops on the wool fabric with nano- $\mathrm{CuO}$ coating did not show a spreading tendency. According to Figure 7 , the contact angle value was on average $84.62^{\circ}$ and $103.27^{\circ}$ on average, respectively. Finally, while the $\mathrm{CuO}$ untreated dyed fabric had hydrophlic wettability, the nanoCuO-impregnated dyed wool fabrics showed hydrophobic wettability.

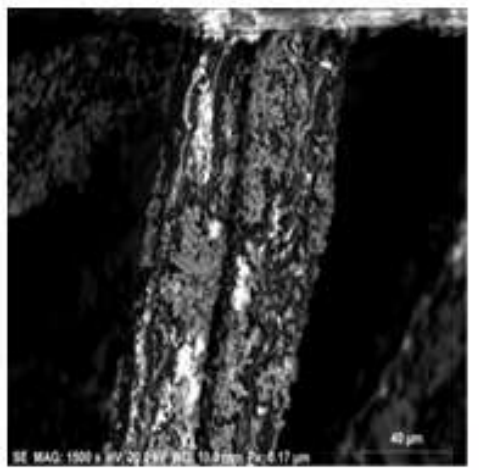

(a)

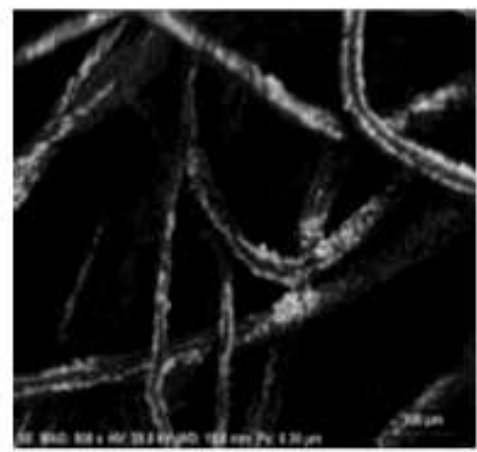

(b)

Fig. 2. SEM images of $\mathrm{CuO}$ nanomaterial treatment of (a) undyed wool fabric, and (b) synthetically dyed wool fabric. The $\mathrm{CuO}$ nanoparticles are well dispersed on the wool fabric surfaces, although some aggregated nanomaterials are still visible.

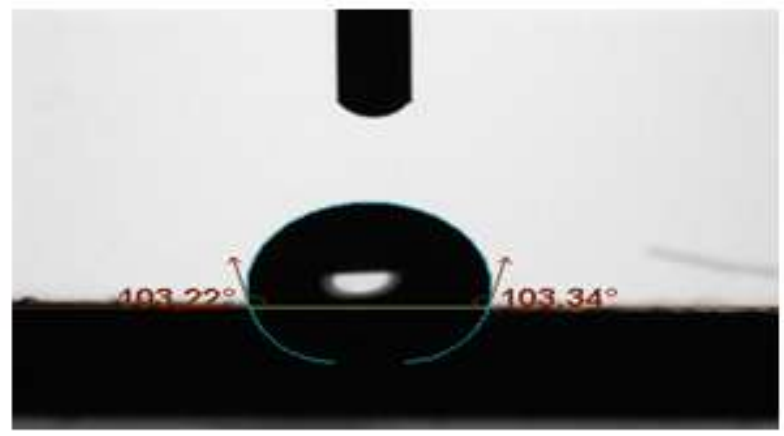

Fig. 4. The view of contact angle on the surface of wool fabric treated with nano-CuO. Water drops on the wool fabric with a nano-

$\mathrm{CuO}$ coating did not show any spreading tendency.

\subsection{Antibacterial activity results}

The quantitative bacterial reduction for $\mathrm{CuO}$ nanomaterial-treated undyed and synthetically dyed wool fabrics was studied with a percentage reduction test (AATCC100) and the results are shown in Table 1. According to Table 1 , while $\mathrm{CuO}$ nanomaterials on undyed wool fabrics have significant antibacterial activity against Staphylococcus aureus, Escherichia coli and Escherichia coli isolated from pasta, $\mathrm{CuO}$ nanomaterials on synthetically dyed wool fabrics have moderate activity against Staphylococcus aureus and are inactive against Escherichia coli and Escherichia coli isolated from pasta. As a result, these nanomaterials are preferable because of higher efficiency in preventing infection. 
Fabric Samples

1. Nano CuO-untreated undyed wool fabric

2. Nano CuO-untreated dyed wool fabric

3. Nano CuO-treated undyed wool fabric

4. Nano CuO-treated dyed wool fabric

TABLE I

ANTIBACTERIAL ACTIVITY OF CUO NANOMATERIAL-TREATED WOOL FABRICS

\begin{tabular}{llll}
\hline $\begin{array}{l}\text { Fabric } \\
\text { sample }\end{array}$ & $\begin{array}{l}\text { Staphylococcus } \\
\text { Aureus }\end{array}$ & E. Coli & $\begin{array}{l}\text { E. Coli isolated } \\
\text { from pasta }\end{array}$ \\
\hline 1 & No reduction & No reduc. & No reduc. \\
2 & No reduction & No reduc. & No reduc. \\
3 & $94.04(\%)$ & $100(\%)$ & $100(\%)$ \\
4 & 40.16 & No reduc. & No reduc. \\
\hline
\end{tabular}

\section{CONCLUSION}

In the present study, the antibacterial activity of $\mathrm{CuO}$ nanomaterials were determined by scanning electron microscope (SEM). SEM images of undyed and dyed fabrics treated with $\mathrm{CuO}$ nanomaterials indicated the presence of various sizes of $\mathrm{CuO}$ nanoparticles. There was good dispersion on the fabric surface and no changes to the structural properties of the fabric and weight or weft and warp densities.

According to the contact angle measurements, while the $\mathrm{CuO}$-untreated dyed fabric had hydrophlic wettability, the nano-CuO-treated dyed wool fabrics demonstrated hydrophobic wettability.

The nanosized CuO-impregnated undyed wool fabric showed significant antibacterial activity against three representative bacteria, Staphylococcus Aureus, Escherichia coli, and Escherichia coli isolated from pasta. They had moderate activity against only Staphylococcus Aureus and were inactive against Escherichia coli and Escherichia coli isolated from pasta on synthetically dyed wool fabrics. This work provides a simple method to impart antibacterial ability onto wool fabric using selected nano composites.

\section{REFERENCES}

[1] R. Dastjerdi and M. Montazer, Colloids and Surfaces B: Biointerfaces, 79,5 (2010).

https://doi.org/10.1016/j.colsurfb.2010.06.023

[2] Y. Gao and R. Cranston, Textile Research Journal, 78 (1), 60 (2014).

[3] P.V. Kamat, The Journal of Physical Chemistry B, 106 (32), 7729 (2002). https://doi.org/10.1021/jp0209289

[4] M. Thomos, Journal of Pure Application Chemistry, 60, 323 (1998).

[5] S. Shanmugam, B. Viswanathan, Bull Mat. Sci., 28, 629 (2005). https://doi.org/10.1007/BF02706354

[6] M.L. Gulrajani, G. Deepti Periyasamy, J. App. Polym. Sci., 108, 614 (2008). https://doi.org/10.1002/app.27584

[7] N. Vigneshwaran, A.A. Kathe J.Nanosci.Nanotech., 7, 1893 (2007). https://doi.org/10.1166/jnn.2007.737

[8] T.W. Chung, P.F. Ng, Q.Chen World J.Text. Engin. Techn., 1, 23 (2015).

[9] K.L. Edwards, Materials \& Design, 19 (1), 1 (1998). https://doi.org/10.1016/S0261-3069(98)00007-7
[10] V.Parthasarathi,G.Thilagavathi,J.Text.App., Techn. Management, 6 (2), 1 (2009).

[11] T. Young, Philosophical Transactions of The Royal Soc. London, 95, 65 (1805). https://doi.org/10.1098/rstl.1805.0005

[12] D.T.W. Chun and G. R. Gamble, Journal of Cotton Science, 1, 154 (2007).

[13] R. Rajendran, C. Balakumar, and J. Kalaivani, J.Text.App.,Techn. Manag., 7 (2), 1 (2011).

[14] S. Agnihotri, S. Mukherji, S. Mukherji, Royal Soc. Chem., 4, 3974 (2014).

Özlen ALTUN was born in Malatya-TURKEY. She graduated from Hacettepe University in 1989 and received her Ph.D. at Trakya University in 2002. 